\title{
KEBIJAKAN HUKUM PIDANA TERHADAP PELAKU PERUNDUNGAN (BULLYING) ANAK DIBAWAH UMUR
}

\author{
Siti Iba Iga Farida, Rochmani \\ Fakultas Hukum, Universitas Stikubank (UNISBANK) Semarang \\ Email : sitiibaigaf@gmail.com,rochmani.unisbank@gmail.com
}

\begin{abstract}
ABSTRAK
Permasalahan terbesar dari anak yang berhadapan dengan hukum adalah karena UU No. 3 Tahun 1997 tentang Pengadilan Anak sudah tidak relevan lagi, baik dari aspek yuridis, filosofis, dan sosiologis. Undang-undang ini tidak memberikan solusi yang tepat bagi penanganan anak sebagai anak yang berhadapan dengan hukum. Anak yang berkonflik dengan hukum yang diselesaikan di pengadilan, berakibat timbulnya tekanan mental dan psikologis terhadap anak yang berkonflik dengan hukum tersebut, sehingg mengganggu tumbuh kembangnya anak. Dengan demikian dengan perlu adanya kebijakan hukum pidana dalam penanganan tindak pidana perundungan (Bullying). Metode penelitian yang digunakan dalam penelitian ini adalah yuridis empiris dengan melihat kenyataan yang ada dalam praktek di lapangan. Tujuan penelitian menjelaskan kebijakan dalam penegakan hukum terhadap pelaku perundungan anak di bawah umur. Penyelesaian hukum pidana pelaku perundungan (bullying) terhadap siswa korban kekerasan di sekolah belum berjalan dengan baik karena perundungan atau bullying sendiri belum diatur dalam undang-undang yang secara khusus mengaturnya.
\end{abstract}

Kata kunci : anak, bawah umur, hukum pidana, kebijakan, perundungan.

\begin{abstract}
The biggest problem for children who are faced with the law is because of Law no. 3 of 1997 regarding Juvenile Court is no longer relevant, both from the juridical, philosophical and sociological aspects. This law does not provide the right solution for the handling of children as children in conflict with the law. Children who are in conflict with the law that is resolved in court, result in mental and psychological pressure on the child who is in conflict with the law, thus disturbing the child's development and development. Thus, there is a need for a criminal law policy in handling bullying. The research method used in this research is juridical empirical by looking at the facts that exist in practice in the field. The research objective is to explain policies in law enforcement against child bullies. Settlement of the criminal law for bullying offenders against student victims of violence at school has not been going well because bullying has not been regulated in a law that specifically regulates it.
\end{abstract}

Keywords : children, underage, criminal law, policy, bullying. 


\section{Pendahuluan}

Pengertian bullying menurut Komnas HAM (Hak Asasi Manusia) adalah sebagai suatu bentuk kekerasan fisik dan psikologis berjangka panjang yang dilakukan seseorang atau kelompok terhadap seseorang yang tidak mampu mempertahankan diri dari situasi ada hasrat untuk melukai atau menakuti orang atau membuat orang tertekan, trauma, depresi dan tidak berdaya ${ }^{1}$. Kasus perundungan atau bullying biasanya menimpa anak sekolah. Pelaku bullying akan mengintimidasi atau mengejek kawannya sehingga kawannya tersebut jengkel.

Dampak negatif yang lebih parah lagi adalah, korban bullying akan mengalami depresi bahkan hingga timbul rasa untuk bunuh diri. Hasil survei KPAI di sembilan provinsi terhadap lebih dari 1000 orang siswa siswi. Baik dari tingkat Sekolah Dasar/MI, SMP/MTs, maupun SMA/MA menunjukan bahwa $87,6 \%$ siswa mengaku mengalami tindak kekerasan. Baik kekerasan fisik maupun psikis, seperti dijewer, dipukul, dibentak, dihina, diberi stigma negatif hingga dilukai dengan benda tajam. Dan sebaliknya $78,3 \%$ anak juga mengaku pernah melakukan tindak kekerasan mulai dari bentuk yang ringan hingga yang berat seperti penghinaan, ejekan baik itu secara langsung atau verbal maupun dengan media sosial ${ }^{2}$.

Kota Semarang tak luput dari adanya perilaku perundungan atau bullying anak di bawah umur. Seperti kasus yang terjadi di SD Negeri Beringin

\footnotetext{
${ }^{1}$ Fitria Chakrawati, 2015, Bullying Siapa Takut?, Tiga Serangkai, Solo, hlm 11.

2 Melista Aulia Nurdina, 2018, Penegakan Hukum Pidana Terhadap Pelaku Tindakan Penindasan atau Bullying di Sekolah Dasar, Jurnal Fakultas Hukum Universitas Lampung Bandar Lampung, hlm. 3.
}

02 Semarang. Kasus bullying atau perundungan ini dialami oleh siswasiswa kelas 2 di SD Negeri Beringin 02 Semarang berinisial PAN. PAN sendiri mengaku pada neneknya sudah mengalami bullying sejak korban masih duduk di kelas 1 SD, saat ini sudah kelas 2. Korban sendiri sehari-hari tinggal bersama nenek dan kakeknya karena sejak bayi sudah ditinggal oleh ayah kandungnya. Sedangkan ibu korban hanya bekerja di kantor koperasi di Semarang. Aksi bullying tersebut diduga berbentuk kekerasan fisik dan perkataan kasar.

Korban berinisial PAN awalnya hanya lempar-lemparan benda tumpul. Kemudian terjadi luka lebam di wajahnya. Menurutnya saat ini kasus bullying tersebut sudah diserahkan ke Dinas Pendidikan Kota Semarang untuk segera diselesaikan. Untuk ke depannya Pemkot akan melakukan pendampingan dan memonitor siswa ini ketika sudah pindah sekolah. Pendampingan akan dilakukan melalui Rumah Duta Revolusi Mental (RDRM). Pihak keluarga korban pun sudah menyetujui untuk pindah sekolah. Sehingga masa depan korban bisa terselamatkan, khususnya dalam mengenyam dunia pendidikan.

Koordinator Satuan Pendidikan UPTD Ngaliyan memastikan, pihaknya akan mencarikan SD negeri yang kuotanya kurang kepada korban. Solusi lain yang ditawarkan adalah dengan mengganti wali kelas korban yang lebih perhatian kepada anak didiknya. Pihaknya mengaku telah memberikan pengertian kepada wali kelas agar lebih memperhatikan siswa, sehingga tindakan bullying baik secara psikis maupun perkataan yang kurang pantas antar siswa tidak akan terjadi. Kasus bullying yang terjadi di SD Negeri Beringin 02 ini menjadi peringatan supaya Pemkot 
Semarang lebih getol melakukan pencegahan supaya tidak terjadi di sekolah-sekolah lain ${ }^{3}$. Permasalahan terbesar dari anak yang berhadapan dengan hukum adalah karena UU No. 3 Tahun 1997 tentang Pengadilan Anak sudah tidak relevan lagi, baik dari aspek yuridis, filosofis, dan sosiologis. Undang-undang ini tidak memberikan solusi yang tepat bagi penanganan anak sebagai anak yang berhadapan dengan hukum. Anak yang berkonflik dengan hukum harus diarahkan untuk diselesaikan ke pengadilan, akibatnya adalah akan ada tekanan mental dan psikologis terhadap anak yang berkonflik dengan hukum tersebut, sehingga mengganggu tumbuh kembangnya anak ${ }^{4}$.

\section{Metode Penelitian}

Jenis Penelitian Penelitian ini menggunakan metode pendekatan yuridis empiris. Pendekatan yuridis empiris yakni dilakukan dengan melihat kenyataan yang ada dalam praktek di lapangan ${ }^{5}$.

Pendekatan ini dikenal pula dengan pendekatan secara sosiologis, yaitu suatu pendekatan dengan berdasarkan norma-norma atau peraturan yang mengikat, sehingga diharapkan dari pendekatan ini dapat diketahui bagaimana hukum yang secara empiris merupakan gejala masyarakat itu dapat dipelajari sebagai suatu variabel penyebab yang menimbulkan akibat-

${ }^{3}$ https : // radarsemarang. jawapos. com/ berita/ semarang/2019/ 12/ 19/ pemkot - monitoring korban - bullying/ Diakses pada 16 Maret 2020, pukul 11.00 WIB.

4 Nasir Djamil, 2013, Anak Bukan Untuk Dihukum: Catatan Pembahasan UU Sistem Peradilan Pidana Anak (UU-SPPA), Sinar Grafika, Jakarta, hlm. 3.

5 Bambang Waluyo, 2002, Penelitian Hukum dalam Praktek, Sinar Grafika, Jakarta, hlm. 15 akibat pada berbagai segi kehidupan sosial ${ }^{6}$.

\section{Spesifikasi Penelitian}

Spesifikasi penelitian yang digunakan oleh penulis dalam penelitian hukum ini adalah deskriptif analitis. Bersifat deskriptif, karena penelitian ini dimaksudkan untuk memberikan gambaran secara rinci, sistematis dan menyeluruh terhadap segala hal yang berhubungan dengan penelitian ini. Adapun deskriptif menurut Taliziduhu Ndraha adalah upaya untuk menemukan pengetahuan tentang obyek research dengan cara menjelaskan secara mendalam (deep descreption $)^{7}$.Selanjutnya analitis, mengandung makna mengelompokkan, menghubungkan, membandingkan dan memberi makna.

\section{Metode Pengumpulan Data}

Penelitian ini menggunakan sumber data primer dan sekunder. Teknik pengumpulan data dalam penelitian ini dilakukan dengan cara wawancara pada beberapa pihak yang dianggap berkepentingan dan mempunyai pengetahuan dan pengalaman tentang penyelesaian hukum pidana oleh pelaku perundungan (bullying) terhadap siswa korban kekerasan di sekolah, yakni Koordinator Rumah Duta Revolusi Mental.

\section{Metode Analisis Data}

Analisis data adalah proses menyusun data agar data tersebut dapat ditafsirkan ${ }^{8}$. Metode analisa data yang dipergunakan dalam penelitian ini adalah metode kualitatif. Analisis data kualitatif

${ }^{6}$ Ronny Hanitijo Soemitro, 1990, Metodologi Penelitian Hukum, Ghalia Indonesia, Jakarta, hlm. 34-35.

7 Taliziduhu Ndraha, 2005, Research Teori Metodologi Administrasi, Bima Aksara, Jakarta, hlm. 105.

8 Dadang Kahmad, 2000, Metode Penelitian Agama, CV Pustaka Setia, Bandung, hlm. 102. 
adalah upaya yang dilakukan dengan jalan bekerja dengan data, mengorganisasikan data, memilahmilahnya menjadi satuan yang dapat dikelola, mensitesiskan-nya, mencari dan menemukan pola, menemukan apa yang penting dan apa yang dipelajari, dan memutuskan apa yang dapat diceritakan kepada orang lain ${ }^{9}$.

\section{Pembahasan \\ Penyelesaian Hukum Pidana Pelaku Perundungan (Bullying) Terhadap Siswa Korban Kekerasan di Sekolah}

Fenomena perundungan (bullying) merupakan salah satu masalah besar yang sejauh ini masih belum bisa diberantas dan diselesaikan secara tuntas di lingkungan institusi Pendidikan. Hal ini dikarenakan, biasanya kejadian terjadi tanpa sepengetahuan pihak yang berwenang di sekolah. Namanya saja ditindas, tentu saja korban takut untuk mengadukan acaman yang diterimanya kepada pihak sekolah. Akhirnya permasalahan ini menjadi sulit dilacak dan terjadi selama bertahun-tahun hingga menimbulkan trauma mendalam pada jiwa si korban. Terkadang, satu orang korban bisa mengalami beberapa jenis perundungan (bullying) sekaligus. Kasus bullying atau perundungan ini juga dialami oleh siswa-siswa kelas $2 \mathrm{di}$ SD Negeri Beringin 02 Semarang berinisial PAN.

Nenek korban bullying atau perundungan tersebut sudah terjadi sejak korban masih duduk di kelas $1 \mathrm{SD}$, saat ini sudah kelas 2. Akibat perlakuan kurang menyenangkan dari beberapa teman satu kelasnya membuat korban trauma untuk berangkat sekolah lagi. Korban sendiri sehari-hari tinggal bersama nenek dan kakeknya karena sejak bayi sudah ditinggal oleh ayah

\footnotetext{
${ }^{9}$ Ronny Hanititjo Soemitro, Op.Cit., hlm. 12.
}

kandungnya. Sedangkan ibu korban hanya bekerja di kantor koperasi di Semarang. Korban mengatakan bahwa ia masih mengingat ketika teman-temannya masih jahil terhadapnya. Bahkan, bullying yang diterima korban tidak hanya berupa perkataan kasar, tetapi juga kekerasan fisik. Parahnya, kekerasan fisik berupa pemukulan dilakukan beberapa kali. Ada yang menggunakan kayu sehingga membuat kening korban berdarah dan harus dibawa ke Puskesmas Ngaliyan.

Akibat kejadian itu, korban sampai menderita demam tinggi. Nenek korban sempat memutuskan untuk mencari sekolah lain. Tapi pihak sekolah pernah mendatanginya dan meyakinkan kalau tidak akan terjadi bullying lagi. Nenek korban juga sudah meminta bantuan kepada Dinas Pendidikan Kota Semarang. Namun belum ada kepastian untuk cucunya bisa bersekolah lagi hingga sekarang.

Saat ini kasus perundungan atau bullying tersebut sudah diserahkan ke Dinas Pendidikan Kota Semarang untuk segera diselesaikan. Pemkot ke depan akan melakukan pendampingan dan memonitor siswa ini ketika sudah pindah sekolah. Solusi untuk kasus bullying ini, lanjutnya, memang tidak hanya serta merta bisa selesai hanya dengan memindah korban ke sekolah yang baru. Kasus bullying yang terjadi di SD Negeri Beringin 02 ini menjadi peringatan supaya Pemkot Semarang lebih getol melakukan pencegahan supaya tidak terjadi di sekolah-sekolah lain. Namun, penyelesaian kasus ini tidak adil bagi korban karena telah mengalami trauma bagi kehidupan. Sehingga, seharusnya pelaku dapat dihukum dengan adil karena kekerasan merupakan termasuk kasus pidana. Perlindungan bagi anak di lingkungan 
Pendidikan merupakan tanggung jawab dari guru, staf pendidik, pemerintah dan masyarakat, sesuai dengan UndangUndang Nomor 23 Tahun 2002 jo Undang-Undang Nomor 35 tahun 2014 tentang Perubahan Atas Undang-Undang Nomor 23 Tahun 2002 Tentang Perlindungan Anak pasal 54 ayat 2 yaitu "perlindungan sebagaimana dimaksud pada ayat (1) dilakukan oleh pendidik, tenaga kependidikan, aparat pemerintah, dan/atau masyarakat".

Berdasarkan wawancara yang dilakukan dalam menindak laporan kasus bullying Rumah Duta Revolusi Mental (RDRM) menggunakan mekanisme yang mengadopsi dari UU Nomor 11 Tahun 2012 tentang Sistem Peradilan Pidana Anak yang mengacu pada keadilan restoratif. Keadilan restoratif selama ini kan di terapkan diformal, istilahnya di mekanisme hukum secara formal yaitu diversi kepolisian. Artinya prinsip yang pertama menganut UU perlindungan anak bahwa namanya anak harus dilindungi. Tetapi kita bukan berarti "harus selalu melindungi anak". Tapi harus lihat Undang-Undang No 11 Tahun 2012. Kalau memang tindak pidananya sangat berat bullying itu sampai mengakibatkan kematian itu sudah mengukuti hukum yang sudah berlaku istilahnya jalur hukum.

Namun, jika masih tindak kekerasan bullying semisal seperti verbal atau pemukulan sekali karena emosi, dilaksanakanlah prinsip keadilan restoratif yang berbentuk mediasi kekeluargaan musyawarah kekeluargaan ${ }^{10}$. Penelitian ini membahas penyelesaian dengan kebijakan dalam

${ }^{10}$ Wawancara dengan Putri Marleney, P. S.Psi, M.Psi, selaku Koordinator Rumah Duta Revolusi Mental (dibawah naungan Pendidikan Kota Semarang), pada tanggal 21 Juli 2020 hukum pidana atau penal. Kebijakan penal digunakan ketika tindak pidana sudah terjadi dan melalui proses hukum di Pengadilan. Kebijakan penal dalam penanggulangan tindak pidana khususnya kejahatan perundungan (bullying) dapat menggunakan peraturan perundangundangan yang ada seperti Pasal Kitab Undang-Undang Hukum Pidana tindak pidana pada umumnya. Mengingat Perundungan (bullying) merupakan tindakan kekerasan terhadap anak, maka menurut Undang-Undang Nomor 23 Tahun 2002 jo UndangUndang Nomor 35 tahun 2014 tentang Perubahan Atas Undang-Undang Nomor 23 Tahun 2002 Tentang Perlindungan Anak, perundungan (bullying) adalah tindak pidana. Terhadap pelaku perundungan (bullying) dapat dikenakan sanksi pidana berupa penjara paling lama 3 (tiga) tahun 6 (enam) bulan dan/atau denda paling banyak Rp 72 juta.

Pasal-pasal yang berkaitan dengan perundungan atau bullying dapat dijadikan acuan untuk pembuatan undang-undang tentang penindasan atau bullying yang sesuai dengan nilai-nilai dalam situasi sekarang dan masa depan, kemudian merumuskan dalam bentuk peraturan perundang - undangan pidana untuk mencapai hasil perundangundangan yang paling baik untuk memenuhi syarat keadilan dan daya guna.

Faktor-Faktor yang Menghambat Penyelesaian Hukum Pidana Pelaku Perundungan (Bullying) Terhadap Siswa Korban Kekerasan di Sekolah Berdasarkan hasil wawancara dengan Rumah Duta Revolusi Mental, bahwa faktor-faktor yang mempengaruhi penegakan hukum dalam tindakan penindasan atau bullying yaitu meliputi faktor penegak hukum, faktor hukum, faktor saran dan prasarana, faktor 
masyarakat dan faktor kebudayaan ${ }^{11}$. Penulis juga mengutip kajian mengenai faktor-faktor yang mempengaruhi penegakan hukum pidana dalam penyelesaian tindak pidana perundungan atau bullying, yaitu sebagai berikut:

1. Faktor Penegak Hukum Dalam kasus perundungan atau bullying sendiri, penegak hukum diharapkan dapat menyediakan tim penyelidik yang cukup untuk pembuktian kasus perundungan atau bullying tersebut serta sumber daya manusia dari aparat penegak hukum itu sendiri agar tidak menganggap remeh kasus penindasan atau bullying.

2. Faktor Hukum Berdasarkan hasil wawancara dengan Putri Marleney, P. S.Psi, M.Psi, selaku Koordinator Rumah Duta Revolusi Mental, bahwa belum adanya peraturan yang sangat dibutuhkan untuk menegakan hukum pidana tentang tindakan perundungan. Perundungan atau bullying sendiri sering kali diselesaikan dengan cara non litigasi atau mendamaikan kedua belah pihak tanpa jalur hukum. Hal tersebut dibenarkan adanya, namun bila Penindasan atau bullying itu sendiri sudah masuk ketahap kriminal seperti, penganiayaan, pemerasan dan lain-lain, jalur hukum dapat ditempuh ${ }^{12}$

3. Faktor Sarana dan Prasarana Dalam proses penegakan hukum, sarana dan prasarna hukum mutlak diperlukan untuk memperlancar dan terciptakan kepastian hukum. Sarana dan prasarana hukum yang memadai dimaksudkan untuk mengimbangi kemajuan teknologi dan globalisasi, yang telah mempengaruhi anak-anak untuk merundung temannya dengan

\footnotetext{
${ }^{11}$ Ibid.,

12 Ibid.,
}

media apapun. Dengan media sosial salah satunya atau biasa kita kenal cyberbullying.

4. Faktor Masyarakat Kesadaran hukum masyarakat yang masih rendah dapat menjadi hambatan bagi proses penegakan hukum. Hal ini dapat dilihat dari masih adanya rasa enggan dalam masyarakat untuk ikut berperan dalam mencegah terjadinya perundungan atau bullying. Peranan orang tua dan keluargalah yang paling berpengaruh untuk menentukan apakah anak-anak mereka dibesarkan oleh kasih sayang dan perhatian yang cukup agar anak tidak melakukan tindakan yang buruk seperti menindas temannya ${ }^{13}$.

5. Faktor Kebudayaan Faktor kebudayaan yakni sebagai hasil karya, cipta dan rasa yang didasarkan pada karsa manusia didalam pergaulan hidup. Faktor kebudayaan yang sebenarnya bersatu padu dengan faktor masyarakat sengaja dibedakan, karen didalam pembahasannya diketengahkan masalah spiritual atau non materiel sebagai suatu sistem (atau subsistem dari sistem kemasyarakatan). Berdasarkan hasil wawancara dengan Putri Marleney, selaku Koordinator Rumah Duta Revolusi Mental, bahwa yang menjadi faktor yang mempengaruhi penegakan hukum pidana terhadap pelaku tindakan penindasan atau bullying di sekolah dasar adalah faktor substansi, faktor penegak hukum, dan faktor budaya hukum ${ }^{14}$

\footnotetext{
${ }^{13}$ Elia Daryati dan Anna Farida, 2014, Parenting With Heart, Kaifa, Jakarta, hlm. 101.

${ }^{14}$ Op.Cit.,
} 


\section{Kesimpulan}

1. Penyelesaian hukum pidana pelaku perundungan (bullying) terhadap siswa korban kekerasan di sekolah belum berjalan dengan baik karena perundungan atau bullying sendiri belum diatur dengan undang-undang khusus, namun aparat penegak hukum menggunakan pasal pokok lain yang mengacu pada atau berkaitan pada penindasan atau bullying. Tindakan yang termasuk kedalam penindasan atau bullying yang sudah diatur dalam UndangUndang Nomor 35 Tahun 2014 tentang Perlindungan Anak dan dalam KUHP yang mengatur tentang pemerasaan dan pengancaman, membuka rahasia, penghinaan dan penganiyaan dan bila diselesaikan dengan jalur hukum diatur dalam UndangUndang Nomor 11 Tahun 2012 tentang Sistem Peradilan Pidana Anak dan akan di jatuhi $1 / 2$ (setengah) dari hukuman yang berlaku untuk orang dewasa.

2. Faktor-faktor yang menghambat penyelesaian hukum pidana pelaku perundungan (bullying) terhadap siswa korban kekerasan di sekolah terdiri dari faktor penegak hukum; faktor hukum; faktor sarana dan prasana; faktor masyarakat serta faktor kebudayaan. Saran Berdasarkan kesimpulan di atas maka peneliti memberikan saran bahwa perlu adanya perundangundangan yang menyebutkan secara jelas hukuman bagi anak yang menjadi pelaku perundungan atau bullying di sekolah, agar adil bagi korban dari tindak perundungan atau bullying karena jika hanya melalui mediasi korban masih mengalami trauma saat dirundung atau dibully.

\section{Daftar Pustaka}

\section{Literatur}

Bambang Waluyo, 2002, Penelitian Hukum dalam Praktek, Sinar Grafika, Jakarta.

Dadang Kahmad, 2000, Metode Penelitian Agama, CV Pustaka Setia, Bandung.

Dellyana, Shant.1988, Konsep Penegakan Hukum. Liberty, Yogyakarta.

Elia Daryati dan Anna Farida, 2014, Parenting With Heart, Kaifa, Jakarta.

Fitria Chakrawati, 2015, Bullying Siapa Takut?, Tiga Serangkai, Solo

M. Nasir Djamil, 2012, Anak Bukan Untuk Dihukum, Sinar Grafika, Jakarta.

Nasir Djamil, 2013, Anak Bukan Untuk Dihukum: Catatan Pembahasan UU Sistem Peradilan Pidana Anak (UUSPPA), Sinar Grafika, Jakarta.

Ronny Hanitijo Soemitro, 1990, Metodologi Penelitian Hukum, Ghalia Indonesia, Jakarta.

S.R. Sianturi, 2002. Asas-asas Hukum Pidana di Indonesia dan Penerapannya, Storia Grafika. Jakarta.

Taliziduhu Ndraha, 2005, Research Teori Metodologi Administrasi, Bima Aksara, Jakarta.

\section{Perundang-Undangan}

Kitab Undang-Undang Hukum Pidana

Undang-Undang Nomor 3 Tahun 1997 tentang Pengadilan Anak

Undang-Undang Nomor 4 Tahun 1979 tentang Kesejahteraan Anak

Undang-Undang Nomor 23 Tahun 2002 jo Undang-Undang Nomor 35 tahun 2014 tentang Perubahan Atas Undang-Undang Nomor 23 Tahun 2002 Tentang Perlindungan Anak

Undang-Undang Nomor 11 Tahun 2012 tentang Sistem Peradilan Pidana Anak 


\section{Artikel/Jurnal}

Fitrian Saefullah, 2016, Hubungan Antara Konsep Diri Dengan Bullying Pada Siswa Siswi SMP, Ejournal Psikologi.

Melista Aulia Nurdina, 2018, Penegakan Hukum Pidana Terhadap Pelaku Tindakan Penindasan atau Bullying di Sekolah Dasar, Jurnal Fakultas Hukum Universitas Lampung Bandar Lampung.

Website

https://radarsemarang.jawapos.com/be rita/semarang/2019/12/19/pemkotmon itoring-korban-bullying/ Diakses pada 16 Maret 2020, pukul 11.00 WIB. 